\title{
Recovery of Mining Wastes in Building Materials: A Review
}

\author{
Alinabiwe Nyamuhanga Ally ${ }^{1,2}$, Manjia Marcelline Blanche ${ }^{3}$, Ursula Joyce Pettang Nana ${ }^{3}$, \\ Masika Muhiwa Grâce ${ }^{1,2}$, Ngapgue François ${ }^{4}$, Chrispin Pettang ${ }^{3}$
}

\author{
${ }^{1}$ Laboratory Engineering Civil and Mechanics, Doctoral Research Unit for Engineering and Applications, University of Yaoundé I, \\ Yaoundé, Cameroon \\ ${ }^{2}$ Department of Civil Engineering, Faculty of Applied Sciences and Technologies, Free University of Great Lakes Countries, \\ Goma, DRC \\ ${ }^{3}$ Department of Civil Engineering, National Advanced School of Engineering of Yaoundé, University of Yaoundé I, Yaoundé, \\ Cameroon \\ ${ }^{4}$ Department of Civil Engineering, Fotso Victor University Institute of Technology, University of Dschang, Bandjoun, Cameroon \\ Email: ir.alny111@gmail.com
}

How to cite this paper: Ally, A.N., Blanche, M.M., Nana, U.J.P., Grâce, M.M., François, N. and Pettang, C. (2021) Recovery of Mining Wastes in Building Materials: A Review. Open Journal of Civil Engineering, 11, 379-397.

https://doi.org/10.4236/ojce.2021.114022

Received: September 2, 2021

Accepted: November 7, 2021

Published: November 10, 2021

Copyright $\odot 2021$ by author(s) and Scientific Research Publishing Inc. This work is licensed under the Creative Commons Attribution International License (CC BY 4.0).

http://creativecommons.org/licenses/by/4.0/

(c) (i) Open Access

\begin{abstract}
The use of materials from waste in buildings compensates for the lack of natural resources, solves the problem of waste management and provides an alternative technique for protection of the environment. There are a large number of industrial wastes that are used for full or partial replacement of raw materials in some construction materials. This review assesses mining waste in concrete as a substitute for aggregates and cement; in fired bricks as a substitute for soil; and in road backfill as a substitute for soil. This paper reviews some mining tailings, mine waste rocks and some slags obtained in the exploitation and/or processing of some ores including iron, gold, lead, phosphate, copper, coal, etc. Different physical properties, mechanical properties, chemical properties, heavy metal content, mineralogic composition, geotechnical properties and environmental properties (leaching test) of the mine wastes were examined. The physical, mechanical and environmental properties of the materials obtained by substitution of raw materials by mine waste were examined and compared to reference materials. Mining waste in cementitious materials offers good compressive strengths, while the porosity of the concrete and/or mortar is a factor influencing its toxicity. As for the waste in fired bricks, fired at a temperature of $900^{\circ} \mathrm{C}$ or more, it offers convincing compressive and flexural strengths. The few research studies obtained on the use of mining waste in road embankments have shown that mining waste can be used as a sub-base layer and backfill as long as it is not toxic. In addition, several other mining wastes require special attention as substitutes for raw
\end{abstract}


materials in construction materials, such as coltan, cobalt.

\section{Keywords}

Mining Waste, Tailings, Waste Rock, Slug, Fired Brick, Backfill Material, Cement Materials

\section{Introduction}

From an economic and environmental point of view, the treatment of the large volumes of waste continuously produced by industrial and urban activities on the one hand, and the depletion of resources on the other, are currently causing problems. Among these waste-producing activities, the mining industry is criticized for the large quantities of mining waste produced during the exploitation of mineral deposits [1]. Nearly 250000 million tonnes of solid waste are produced annually by mining activities in several forms [2]. Mining activities include mining, mineral processing and metallurgical extraction. Underground or open pit mining operations generate three main types of solid waste: rock waste in the form of rock fragments representing the non-commercial portion of the extracted rock, concentrator tailings consisting of gangue, water and sometimes chemical additives used during the ore processing phase, and finally contaminated water treatment sludge [2]. In addition to rock waste and tailings, dead soil excavated during mining operations is also considered to be mining waste. Geologically heterogeneous, mining waste is a material made up of sedimentary, metamorphic or igneous rocks, soils and loose sediments ranging in size from fine particles to boulders. In addition to occupying large areas, mining waste causes serious environmental problems and significant ecological disturbances if not properly controlled. It represents one of the major sources of industrial waste requiring particular attention from the scientific community due to the enormous volumes involved [3] [4]. Increasing attention has been paid to the use of waste in construction materials, including concrete, road backfill, fired bricks and ceramics [1] [5] [6]. This application is motivated by the exhaustibility of natural resources and the promotion of sustainable development by promoting a circular economy.

Researchers around the world have multiple views on the potential use of mining waste; some researchers suggest that depending on their properties, mining waste can partially or fully replace aggregates and cement in concrete, clay, fired bricks, etc. This review collects, categorizes and summarizes the use of different types of mining waste in construction materials including concrete (cement, sand and aggregate), fired bricks (clay) and backfill materials (soil).

This paper presents an overview of the characteristics of mining waste and its use in construction materials, particularly in concrete, fired bricks and backfill materials. The results will be expressed in origins and typologies of mining wastes, 
characteristics of mining wastes and characteristics of materials containing mining wastes. The review presented is structured in two main sections, namely the methodology used (Section 2) and the results obtained (Section 3).

\section{Methodology}

The methodology used to obtain an overview of the use of mining waste in construction materials is based on a thorough review of research into the use of mining waste in construction materials, particularly in cementitious materials (concrete and mortar), fired bricks and backfill materials. The bibliography reviewed in this paper includes publicly defended theses, articles published in academic journals, peer-reviewed thematic conferences and case studies. The keywords and terminology used in the literature were associated with mine waste and construction materials including mine waste (tailings, waste rock, slag), concrete, mortar, mechanical strength, workability, fired bricks and road fill. The literature review consisted of

- Highlighting the main origins and typologies of mining waste;

- Highlighting some properties of mining wastes, in particular physical properties (particles gradation, specific gravity, bulk gravity, water absorption); mechanical properties (the modulus of elasticity; wear resistance; los Angels coefficient); chemical composition; heavy metals and metalloids content, mineralogical composition, geotechnical properties (angle of internal friction, cohesion, atterberg limits, ...) and environmental properties (leaching test), compared to the US-EPA standard on waste characteristics;

- Presentation of the physical, mechanical and environmental properties of construction materials (concrete, mortar, fired bricks, backfill materials) obtained by partial or total substitution of the raw material by mining waste.

\section{Presentation of the Results}

\subsection{Origins and Typology}

In mining, mineralized wastes come from three main sources: mining exploitation, mineral processing and metallurgical processing.

The typology of mining waste depends on its origin. Indeed, inefficiencies due to multiple factors at each level lead to mineral losses in waste rock, tailings, slag and leached ore. Mining water, which comes into contact with solid waste, either naturally or by being introduced during one of the production stages, is also a mining waste. When used, it is loaded with dissolved metals and is characterized by its mobility, thus contributing to the spread of environmental contamination [7]. Lottermoser provides a comprehensive overview and detailed description of the different types of mining waste and their sources, summarized in Figure 1. In addition, any mineralized material that is not exploited on site can be considered as mining waste [2]. In particular, a portion of the ore body left exposed and unmined may also come into contact with mining waters, contributing to dissolved metal releases. 


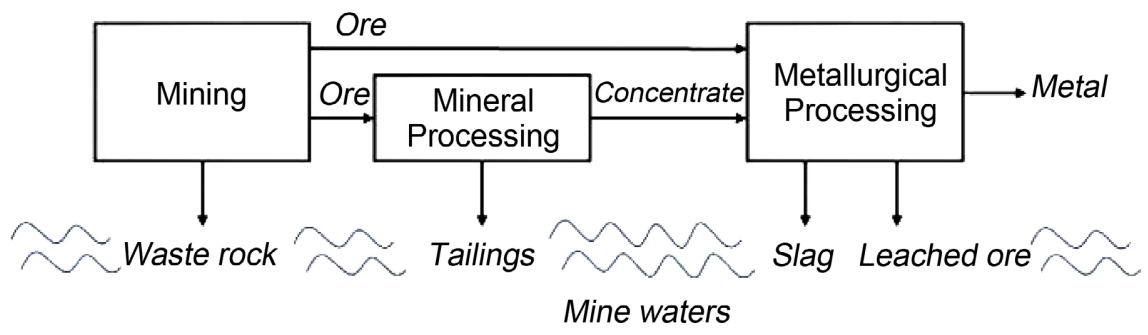

Figure 1. Origins of mineralised waste [2].

\subsection{Characteristics of Mining Waste}

\subsubsection{Physical Properties}

The physical properties of mining wastes, such as particle size distribution, specific gravity, bulk density and water absorption rate are sufficient to confirm their ability for use in construction materials (concrete, fired bricks, road fill) to be recognised.

\section{1) Particles gradation}

The size distribution of phosphate miningrock waste is about $100 \%$ between $6.3 \%$ and $25 \mathrm{~mm}$ according to El Machi [8]. The particle size distribution of gold mining waste rock is between 0 and $20 \mathrm{~mm}$, of which $14 \%$ is less than $0.1 \mathrm{~mm}$; $10 \%$ is between $0.1 \mathrm{~mm}$ and $0.6 \mathrm{~mm}$; about $30 \%$ is between $0.6 \mathrm{~mm}$ and $5 \mathrm{~mm}$ and about $46 \%$ is between $5 \mathrm{~mm}$ and $20 \mathrm{~mm}$ [9]. The particle size distribution of dry compacted phosphate miningrock waste is between $0.001 \mathrm{~mm}$ and $100 \mathrm{~mm}$ of which $25 \%$ is between $0.001 \mathrm{~mm}$ and $0.5 \mathrm{~mm} ; 10 \%$ is between $0.5 \mathrm{~mm}$ and 20 $\mathrm{mm}$ and $50 \%$ is between $20 \mathrm{~mm}$ and $100 \mathrm{~mm}$ [10].

More than $30 \%$ of phosphate processing slags consists of ultrafine particles $(<5.0 \mu \mathrm{m})$, while its equivalent diameter (D50) is $8.3 \mu \mathrm{m}$, with more than $80 \%$ of the particles being fines $(<25 \mu \mathrm{m})$ [11]. Table 1 shows the particle size of some mining waste obtained by some researchers.

On the one hand, it can be observed that the particle distribution of mining waste ranges from fines to gravel, and on the other hand, the particle size of mining waste depends on the type of waste, the ore mined and the process used to obtain the ore.

\section{2) Specific density}

The specific gravity of iron tailing obtained by Xingfong et al. [6] is about $3.51 \pm$ 0.4; that of gold mine tailing obtained by Ceren Ince is 3.46 [13]. The specific gravity of gold mine waste rock reported by Youssef Bernachid et al. [9] and Y. Taha et al. [14] is approximately between 2.7 and 3.5. Several researchers have reported the specific gravity as shown in Table 2.

\section{3) Bulk density}

The bulk density of some mining wastes obtained by some researchers is mentioned in Table 2. Y. Taha et al. [14] mention that the bulk density of gold miningrock waste is 1.56 - 1.65 while R. Argane et al. [15] have a bulk density between 1.380 and 1.56 .

4) Water absorption 
Table 1. Granulometric characteristics.

\begin{tabular}{|c|c|c|c|c|c|c|c|c|c|c|}
\hline Wastes & $\mathrm{d}(\mu \mathrm{m})$ & $\mathrm{D}(\mu \mathrm{m})$ & $<63 \mu \mathrm{m}$ & $<80 \mu \mathrm{m}$ & $\begin{array}{l}\mathrm{D} 10 \\
(\mu \mathrm{m})\end{array}$ & $\begin{array}{l}\mathrm{D} 30 \\
(\mu \mathrm{m})\end{array}$ & $\begin{array}{l}\mathrm{D} 50 \\
(\mu \mathrm{m})\end{array}$ & $\begin{array}{l}\mathrm{D} 80 \\
(\mu \mathrm{m})\end{array}$ & $\begin{array}{l}\mathrm{D} 90 \\
(\mu \mathrm{m})\end{array}$ & MF \\
\hline \multirow[t]{5}{*}{ Iron tailing [6] } & 0 & 5000 & - & - & - & - & - & - & - & - \\
\hline & 5000 & 20,000 & - & - & - & - & - & - & - & - \\
\hline & 20,000 & 40,000 & - & - & - & - & - & - & - & - \\
\hline & 40,000 & 80,000 & - & - & - & - & - & - & - & - \\
\hline & 80,000 & 150,000 & - & - & - & - & - & - & - & - \\
\hline \multirow[t]{4}{*}{ Gold tailing [12] } & 1 & 100 & - & - & 1.8 & - & 5.6 & - & 43.67 & - \\
\hline & 1 & 100 & - & - & 1.8 & - & 4.4 & - & 13.0 & - \\
\hline & 50 & 100 & - & - & 11.0 & - & 30.6 & - & 52.0 & - \\
\hline & 50 & 300 & - & - & 81.2 & - & 128.6 & - & 205.4 & - \\
\hline Gold-mine tailings [13] & 1 & 100 & - & - & - & - & - & - & - & \\
\hline \multirow[t]{2}{*}{ Waste rock gold mining [9] } & 0 & 5000 & - & - & - & - & - & - & - & 2.12 \\
\hline & 5 & 20,000 & - & - & - & - & - & - & - & - \\
\hline Waste rock gold mine [14] & 0 & 20,000 & - & $20-24$ & - & - & - & - & - & - \\
\hline \multirow[t]{2}{*}{ Lead tailing [15] } & 5 & 704 & 14 & - & - & - & - & - & - & - \\
\hline & 5 & 418.6 & 48.24 & - & - & - & - & - & - & - \\
\hline Phosphate mine waste rock [16] & 800 & 80,000 & - & - & - & - & - & - & - & - \\
\hline \multirow[t]{2}{*}{ Flint from phospahate mine waste rock [17] } & 6300 & 15,500 & - & - & - & - & - & - & - & - \\
\hline & 12,500 & 25,000 & - & - & - & - & - & - & - & - \\
\hline Phosphate processing sludge [11] & & & - & - & 2.4 & 5 & 8.3 & 17.2 & - & - \\
\hline $\begin{array}{l}\text { (Dry compacted phosphate mine } \\
\text { waste rock) [10] }\end{array}$ & 0 & 100,000 & - & - & - & - & - & - & - & - \\
\hline Phosphate mine waste rocks $[8]$ & 10,000 & 20,000 & - & - & - & - & - & - & - & - \\
\hline Copper tailing [5] & 0 & 2000 & - & - & - & - & - & - & - & 1.573 \\
\hline
\end{tabular}

Xingdong et al. [6] performed the absorption of ion tailings and found $0.2 \%$ and $1.22 \%$. Sukhoon Pyo et al. [12] observed that the water absorption of gold tailings is $1.21 \%$ and $2.67 \%$, while Ceren Ince [13] stated that the water absorption of gold tailings is $7.15 \%$. The water absorption capacity of gold mine waste rock reported by Youssef Bernarchi et al. [9] is 2.05\%. A. El. Machi et al. [8] found the water absorption of $5.2 \%$ for phosphate mine waste. Table 2 reports the water absorption of mining waste obtained by researchers.

It can be seen from the physical properties presented in this section that the distribution of mining waste particles ranges from fine to coarse; the specific gravity is between 2.55 and 3.925 and water absorption is between $0.2 \%$ and $5.2 \%$. Furthermore, it can be noted that the physical properties, in particular the granulometry, specific density and water absorption of mining waste, are a function of the type of waste, the ore mined and the process used to obtain the ore. 
Table 2. Specific density, bulk density, water absorption.

\begin{tabular}{|c|c|c|c|c|c|}
\hline Mining wastes & Abs (\%) & $\begin{array}{l}\text { Specific } \\
\text { density }\end{array}$ & $\begin{array}{l}\text { Blaine specific } \\
\text { surface area } \\
\left(\mathrm{cm}^{2} / \mathrm{g}\right)\end{array}$ & $\begin{array}{l}\text { Bulk density } \\
\left(\mathrm{kg} / \mathrm{m}^{3}\right)\end{array}$ & $\mathrm{w}(\%)$ \\
\hline \multirow[t]{5}{*}{ Iron tailing [6] } & 1.22 & 3.120 & - & - & - \\
\hline & 0.4 & 3.715 & - & - & - \\
\hline & 0.2 & 3.225 & - & - & - \\
\hline & 0.2 & 3.285 & - & - & - \\
\hline & 0.2 & 3.925 & - & - & - \\
\hline \multirow[t]{4}{*}{ Gold tailing [12] } & 2.67 & - & - & - & - \\
\hline & 2.1 & - & - & - & - \\
\hline & 2.6 & - & - & - & - \\
\hline & 2.6 & - & - & - & - \\
\hline Gold-mine taillings [13] & 7.15 & 3.46 & 368 & & \\
\hline \multirow[t]{2}{*}{ Waste rock gold mining [9] } & 2.04 & 2.68 & - & - & - \\
\hline & 0.84 & 3.42 & - & - & - \\
\hline \multirow[t]{2}{*}{ Waste rock gold mine [14] } & 0.7 & 2.73 & - & 1650 & - \\
\hline & 2.04 & 3.45 & - & 1560 & - \\
\hline \multirow[t]{2}{*}{ Tailling plomb [15] } & 0.7 & 2.7 & - & 1380 & - \\
\hline & 0.7 & 3.12 & - & 1560 & - \\
\hline \multirow[t]{2}{*}{ Flint from phospahate mine waste rock [17] } & 1.57 & 2.57 & - & - & 0.2 \\
\hline & 1.58 & 2.55 & - & - & 0.18 \\
\hline Phosphate processing sludge [11] & & 2.47 & - & - & \\
\hline Dry compacted phosphate mine waste rock [10] & 2.664 & - & - & - & - \\
\hline Phosphate mine waste rocks [8] & 5.2 & - & - & - & 0.1 \\
\hline Copper tailing [5] & - & 3.10 & - & - & - \\
\hline
\end{tabular}

\subsubsection{Mechanical Properties}

Xingdong et al. [6] performed the compressive test on iron tailings, and found the compressive streght of $160 \mathrm{Mpa}$ and $131 \mathrm{Mpa}$ in dry and wet state respectively, with iron tailings Young's modulus of $81 \mathrm{Mpa}$ in the dry state and $65 \mathrm{Mpa}$ in wet state. Aiman and Machi et al. [17] working on the flint from phosphate mine waste rock found the microdeval wear resistance of $9.8 \%$ and Los Angels coefficient of 19\%. A. El Machi et al. [8] working on phosphate mine waste rock observed Los Angeles coefficient is $41 \%$ and Microdeval wear resistance is $43 \%$; while Mustapha Amran et al. [16] noted that the Los Angels coefficient of phosphate mine waste rock is between $45 \%-58 \%$ with a Microdeval coefficient between $50 \%-70 \%$. In the light of the results of these researchers, it is observed that the resistance to impact and wear is primarily related to the mineralogical constitution of the mine waste tested. 


\subsubsection{Chemical Properties}

Xingdong et al. [6] observed that almost $85.5 \%$ of iron tailings consist of silica, alumina, ferric oxide and calcium oxide distributed as follows: $38.3 \% \mathrm{SiO}_{2} ; 15.8 \%$ $\mathrm{Al}_{2} \mathrm{O}_{3} ; 15.6 \% \mathrm{Fe}_{2} \mathrm{O}_{3}$ and $15.8 \% \mathrm{CaO}$. Sukhoon Pyo et al. [12] found that Gold tailings consist of $60 \%$ to $80 \%$ by silica. M. Ettoumi et al. [11] observed that $55.9 \%$ of the phosphate processing slag consists of silica and calcium oxide (39\% $\mathrm{SiO}_{2} ; 16.9 \% \mathrm{CaO}$ ). Aiman and Machi et al. [8] observed that $92 \%$ of the flint from phosphate mine waste rock is silica. The chemical constitutions of some mining wastes obtained by some researchers are presented in Table 3.

It is observed from the afore presented chemical constitutions that the chemical properties of iron tailings are functions of the nature of ore exploited, the treatment of the minerals and the metallurgical treatment employed.

Table 3. Chemical composition of some mining wastes.

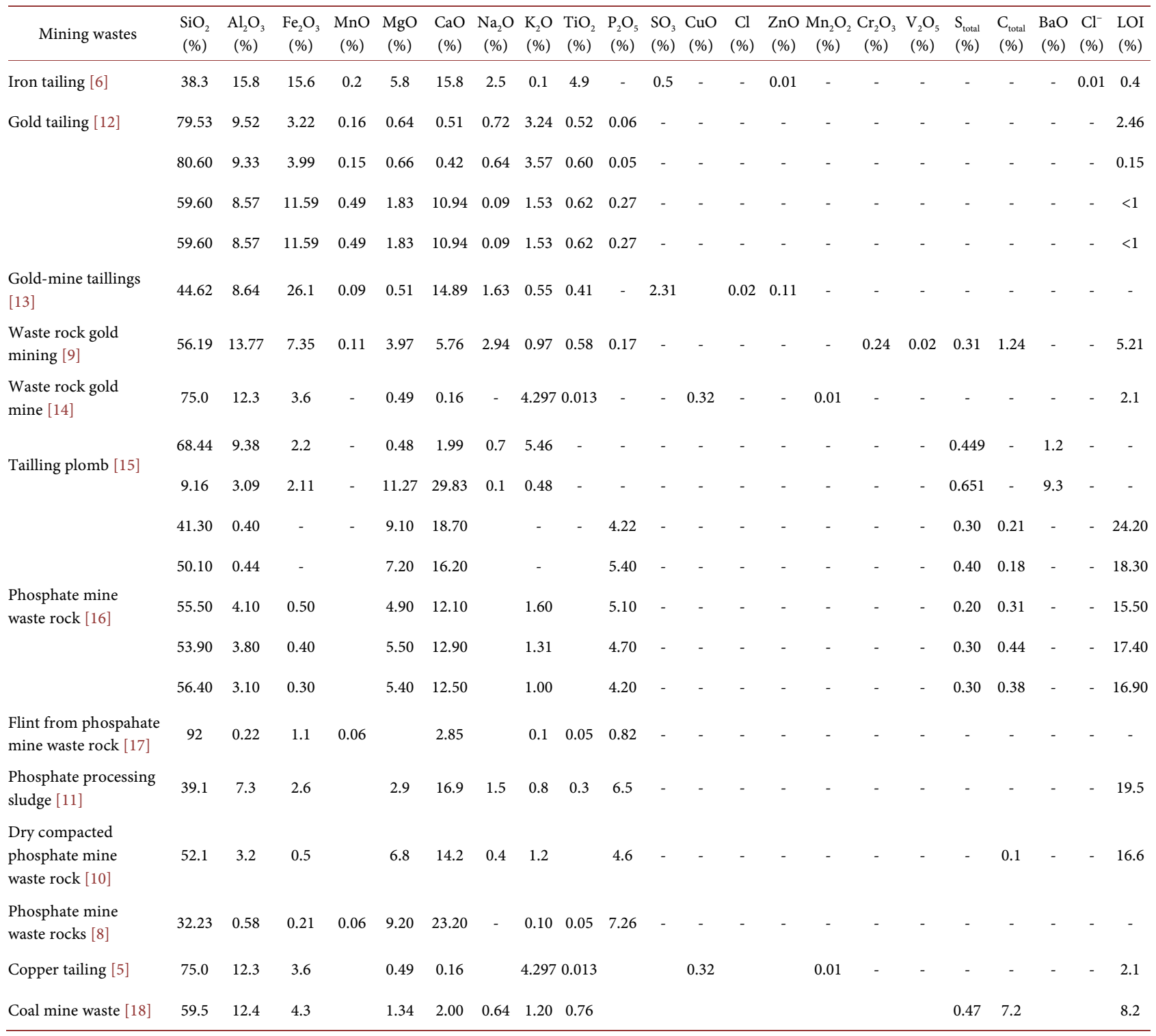




\subsubsection{Heavy Metal Content}

In addition to different chemical compositions presented above, there is a particular interest in heavy metals and metalloids present in mining waste. Table 4 shows some of the heavy metals and metalloids that some researchers have observed in some mining wastes. Furthermore, it can be observed that the content of heavy metals in mining waste is related to the nature of ore exploited.

\subsubsection{Mineralogic Composition}

Several researchers evaluated the mineralogical composition of mine waste. Xingdong et al. [6] observed that iron tailings consists of 31\% of Quartz, $26.1 \%$ of Albite and $15.8 \%$ of Chamosite. Y. Taha et al. [14] observed that gold mining waste consists of $37.6 \%$ quartz, $27.1 \%$ albite and $15.3 \%$ albite. Mustapha Amrani et al. [16] observed that phosphate miningrock waste consists of $41 \%$ quartz and 40.89\% dolomite. M. Ettoumi et al. [11] as for them observed a mineralogical composition of phosphate processing sludge of $29 \%$ quartz, $23 \%$ calcite, $15 \%$ fluorapatite and $11.9 \%$ vermiculite. Table 5 explicitly presents the different mineralogical compositions of some mining wastes obtained by researchers. It can be seen that the mineralogical composition of the different mining wastes is closely related to the chemical composition, but also depends on crystallization conditions of the ore that is exploited. Furthermore, the mineralogical composition of rock waste depends on the type of rock and its associated primary and secondary minerals; that of tailings and slags depends not only on the mineral processed but also on its degree of oxidation (exposure to water, bacteria and oxygen).

\subsubsection{Geotechnical Properties}

Some researchers tried to evaluate the geotechnical properties of mining waste such as coal mining waste and phosphate miningrock waste; the results are

Table 4. Heavy metal content $(\mathrm{mg} / \mathrm{kg})$.

\begin{tabular}{lccccccccccccc}
\hline & $\mathrm{As}$ & $\mathrm{Ba}$ & $\mathrm{Cd}$ & $\mathrm{Co}$ & $\mathrm{Cr}$ & $\mathrm{Cu}$ & $\mathrm{Mn}$ & $\mathrm{Mo}$ & $\mathrm{Ni}$ & $\mathrm{Pb}$ & $\mathrm{Se}$ & $\mathrm{Zn}$ & $\mathrm{Fe}$ \\
\hline Gold tailing [12] & 282.4 & - & - & - & - & 75.2 & - & - & - & 195.9 & - & 78.8 & 325 \\
& 0.84 & - & - & - & - & 70.1 & - & - & - & 190.48 & - & 70.1 & 335 \\
& 225.4 & - & 13.5 & - & - & - & - & - & - & 11.5 & - & 93.5 & 3154 \\
& 225.4 & - & 13.5 & - & - & - & - & - & - & 11.5 & - & 93.5 & 3154 \\
& - & - & 0.31 & - & 7 & 32 & - & - & - & 62 & - & 287 & - \\
Gold-mine taillings [13] & 607 & 300 & $<5$ & 40 & 1320 & 309 & 724 & 55 & 429 & $<5$ & 33 & $<55$ & - \\
Waste rock gold mining [9] & $<30$ & - & $<5$ & 36 & 225 & - & 387 & 37 & 67 & 8 & - & $<55$ & - \\
Waste rock gold mine [14] & 607 & 300 & $<5$ & 40 & 1320 & 309 & 724 & 55 & 429 & $<5$ & 33 & $<55$ & - \\
& 30 & - & - & - & 90 & 130 & - & 110 & - & 4210 & - & 230 & - \\
Tailling plomb [15] & 20 & - & - & - & 50 & 20 & - & 2.3 & - & 20 & - & 260 & - \\
& & & & & & & & & & & & &
\end{tabular}


Table 5. Mineralogical composition of some mining wastes.

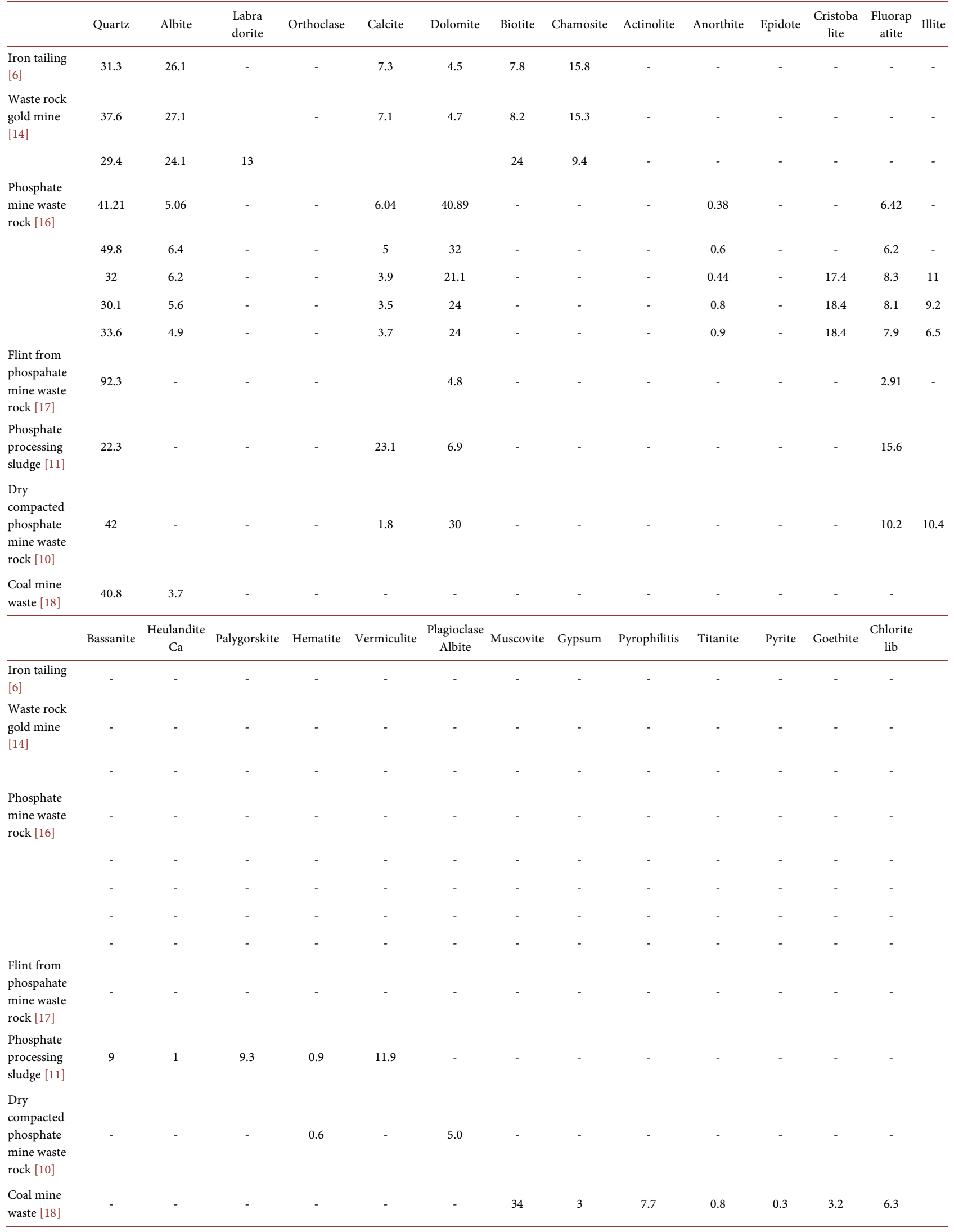


presented in Table 6, which shows that their geotechnical properties function on the particle size of the mine waste.

\subsubsection{Environmental Properties (Leaching Test)}

The general objective of leaching tests is to determine the number of chemical species present in waste or waste-based materials in a given leachant. In other words, the leachate test is a test in which a material is brought into contact with a leachant and certain constituents of the material are extracted. The results of the TCLP (Toxicity Characteristic Leaching Procedure) test of some mining wastes obtained by some researchers are summarized in Table 7 . The concentrations of leached heavy metals and metalloids are mostly low and below the thresholds set for granular wastes in the US-EPA Waste Characteristic Specifications [19]. Furthermore, it is observed that the mobility of chemical species present in mining waste in a given leachate is directly related to the level of heavy materials containing it, but also to the leachate used.

\subsection{Overview in Building Materials}

\subsubsection{Mining Waste in Cementitious Materials}

Infrastructure and civil engineering development keeps on increasing each year, making concrete the most widely used construction material in the world compared to steel, wood, plastic and aluminum [20]. Each year, the use of concrete is estimated to around 11 billion metric tons [21]. Coarse aggregates occupy $60 \%$ $80 \%$ of the volume of concrete and play a crucial role in the development of the mechanical properties of concrete [22] [23] [24]. The demand for aggregates for the concrete industry is constantly increasing, resulting in the depletion of natural resources. In order to reduce the dependence on natural aggregates, many researchers have investigated the substitution of natural aggregates with industrial by-products as an alternative for the construction industry [25]-[30].

A. El Machi et al. [8] showed in an experimental study that mixing concrete with Flint from phosphate miningrock waste required an additional amount of water compared to mixing natural aggregates in order to obtain the desired workability. Furthermore, in terms of compressive, flexural and tensile strength at 28 days, waste rock concretes have a lower range of strengths compared to natural aggregate based concretes and are therefore not intended in terms of performance for structural concretes, but may be suitable for other uses such as perimeter walls and sidewalks. This approach can also be beneficial to mining

Table 6. Geotechnical properties of mine waste.

\begin{tabular}{|c|c|c|c|c|c|c|c|c|c|}
\hline Waste & $\rho\left({ }^{\circ}\right)$ & $\mathrm{C}(\mathrm{Mpa})$ & $\begin{array}{l}\mathrm{Wl} \\
(\%)\end{array}$ & $\begin{array}{l}\text { WP } \\
(\%)\end{array}$ & IP (\%) & $\mathrm{Cc}$ & Cs & $\begin{array}{l}\sigma(\mathrm{P}) \\
(\mathrm{kPa})\end{array}$ & $\mathrm{VBM}$ \\
\hline Coal mine waste rock [18] & 30 & 13 & 42 & 25 & 17 & 0.15 & 0.04 & 80 & 0.89 \\
\hline $\begin{array}{l}\text { Phosphate mine waste } \\
\text { rock [16] }\end{array}$ & $27-32.4$ & $4-7$ & $37-45$ & $25-30$ & $12-15$ & - & - & - & $0.58-0.71$ \\
\hline
\end{tabular}


Table 7. Environmental property (mg/litre).

\begin{tabular}{|c|c|c|c|c|c|c|c|c|c|c|c|c|c|c|c|c|c|c|c|}
\hline $\begin{array}{l}\text { Mining } \\
\text { wastes }\end{array}$ & As & $\mathrm{Ba}$ & B & $\mathrm{Cd}$ & $\mathrm{Cr}$ & $\mathrm{Hg}$ & $\mathrm{Pb}$ & $\mathrm{Se}$ & $\mathrm{U}$ & $\mathrm{Cu}$ & $\mathrm{Fe}$ & Mo & $\mathrm{Zn}$ & $\mathrm{V}$ & $\mathrm{Be}$ & $\mathrm{Bi}$ & Co & $\mathrm{Mn}$ & $\mathrm{Ni}$ \\
\hline $\begin{array}{l}\text { Waste rock } \\
\text { gold mining } \\
\text { [9] }\end{array}$ & $<0.06$ & 0.19 & 0.03 & $<0.003$ & $<0.003$ & 0.00012 & $<0.0003$ & & - & - & - & - & - & - & - & - & - & - & - \\
\hline $\begin{array}{l}\text { Waste rock } \\
\text { gold mine [14] }\end{array}$ & 0.0011 & 0.22 & & 0.001 & 0.001 & & 0.0011 & & & 0.043 & & 0.001 & 0.08 & & 0.0011 & 0.0011 & 0.007 & 7.25 & 0.0011 \\
\hline & 0.0011 & 0.63 & & 0.001 & 0.007 & & 0.0011 & & & 0.0011 & & 0.001 & 0.04 & & 0.0011 & 0.0011 & 0.0011 & 3.15 & 0.021 \\
\hline \multirow[t]{3}{*}{$\begin{array}{l}\text { Plomb } \\
\text { tailling [15] }\end{array}$} & $<0.06$ & 1.08 & & & $<0.003$ & & 232 & & & 0.454 & 0.221 & $<0.009$ & 0.645 & & - & - & - & - & - \\
\hline & 0.072 & 0.586 & & $<0.003$ & & 5.26 & & & 0.18 & 0.07 & $<0.009$ & 103 & 0.072 & & - & - & - & - & - \\
\hline & $<1$ & & & $<0.10$ & $<0.20$ & & $<0.60$ & $<0.10$ & & $<0.50$ & & & 0.55 & $<1$ & - & - & - & - & - \\
\hline \multirow{4}{*}{$\begin{array}{l}\text { Phosphate } \\
\text { mine waste } \\
\text { rock [16] }\end{array}$} & $<1$ & & & $<0.10$ & $<0.20$ & & $<0.60$ & $<0.10$ & & $<0.50$ & & & 0.62 & $<1$ & - & - & - & - & - \\
\hline & $<1$ & & & $<0.10$ & $<0.20$ & & $<0.60$ & $<0.10$ & & $<0.50$ & & & 0.73 & $<1$ & - & - & - & - & - \\
\hline & $<1$ & & & $<0.10$ & $<0.20$ & & $<0.60$ & $<0.10$ & & $<0.50$ & & & 0.54 & $<1$ & - & - & - & - & - \\
\hline & $<1$ & & & $<0.10$ & $<0.20$ & & $<0.60$ & $<0.10$ & & $<0.50$ & & & 0.56 & $<1$ & & & & & \\
\hline $\begin{array}{l}\text { Phosphate } \\
\text { processing } \\
\text { sludge [11] }\end{array}$ & 0.07 & 0.016 & 0.071 & 0.011 & - & $<0.02$ & - & - & - & - & - & - & 0.058 & - & - & - & - & - & - \\
\hline $\begin{array}{l}\text { Limits } \\
\text { (US-EPA) } \\
{[19]}\end{array}$ & 5 & 100 & 500 & 1 & 5 & 0.2 & 5 & 1 & 2 & - & - & - & 2 & - & - & - & - & - & - \\
\hline
\end{tabular}

companies, who can ensure the manufacture of sidewalks and boundary walls at their mining sites, rather than importing these materials from outside.

Aiman El Machi et al. [17] showed that the complete replacement of natural aggregates by flint aggregates, from phosphate waste rocks in the production of B25 concrete showed significant performance in terms of compressive strength, which reached an average of $29 \mathrm{MPa}$ at 28 days, with a slightly lower dry concrete density than the reference concretes, significant flexural strength indicating the good interlocking between the flint aggregates and the hardened cement paste. Their results were able to show that flint aggregates, derived from phosphate waste rocks in concrete, is an alternative to reduce the environmental and economic problems related to the production of mining waste and the depletion of natural resources.

Ceren Ince [13] showed that the compressive strength of cement mortars with replacement of cement and sand by gold residues respectively is increasing up to $30 \%$ replacement. This observed increase was mainly due to the finer particle size of the gold residues used as filler material, which reduced the porosity and densified the microstructure of the matrix on the one hand and on the other hand it was due to the pozzolanic character of the gold residues. The porosity decreases with the substitution of the sand and cement by the gold residues. 
R. Argane [15] was able to show that the use of lead tailings as aggregates in cement mortar requires an additional quantity of water thus implying an increase of the $\mathrm{W} / \mathrm{C}$ ratio. The tailings-based mortars present relatively good properties at 28 days between $8.58 \mathrm{Mpa}$ and $10.9 \mathrm{MPa}$. Furthermore, R. Argane explains that the presence of heavy metals such as $\mathrm{Pb}$ and $\mathrm{Zn}$ in the residues delays the process of main cement hydration products ( $\mathrm{CSH}$ and $\mathrm{Zn}$ ), cement hydration products (CSH and portlandite) by creating an impermeable coating around the clinker, impermeable coating around the non-hydrated cement clinker grains.

Some researchers have had to quantify the variability of chemical elements present in mine waste-based cementitious materials. The leaching test is a test in which a material is put in contact with a leachant so that certain constituents of the materials are extracted. Table 8 presents the characteristics of cementitious materials derived from mining waste while Table 9 presents the leaching results observed by some researchers on cementitious materials made from mining waste. The different values in Table 9 indicate that most of the leaching test results carried out on cementitious materials with mining waste show that the leaching of heavy metals and sulphates is below the limit requirements set by the Soil Quality Decree.

It is observed from the results of previous studies that cementitious materials offer the possibility of absorbing mining wastes especially wastes rocks and tailings in different proportions. The results that mining wastes offer in cementitious materials are usable in civil engineering. Furthermore, the porosity of concrete and/or mortar is a factor that affects their toxicity.

\subsubsection{Mining Waste in the Manufacture of Fired Bricks}

M. Ettoumi et al. [11] observed that the optimum properties of fired bricks obtained from Phosphate sludge were at $1100 \mathrm{C}$, with a porosity of $9 \%$, a firing shrinkage of $7.5 \%$, a water absorption of $12.5 \%$, a bulk density of $1.4 \mathrm{~g} / \mathrm{cm}^{3}$ and a flexural strength of $13.4 \mathrm{MPa}$; with satisfaction in terms of metal concentrations and potential mobility and toxicity requirements.

Table 10 presents the different characteristics of the bricks obtained from mining waste where it can be read that there is a significant improvement of physical and mechanical properties with the increase of the firing temperature. Therefore, it appears that the production of bricks from mining waste is a promising option for the sustainable management of waste materials, which are worthless and abundant, to preserve soils that are currently often overexploited for their disposal, to reduce their environmental footprint and to minimize the exploitation of nonrenewable resources already used in the manufacture of bricks.

In general, the results of previous studies have shown that the use of mining wastes especially slags is practical in fired bricks. These offer preponderant properties. Moreover, the firing of these influences the decrease of the toxicity of the produced bricks. 
Table 8. Properties of cementitious materials from mine waste.

\begin{tabular}{|c|c|c|c|c|c|c|c|c|c|}
\hline Mining waste & Recovered as & $\mathrm{W} / \mathrm{C}$ & $\begin{array}{c}\text { Rate of } \\
\text { replacement } \\
(\%)\end{array}$ & $\begin{array}{l}\text { Slump } \\
\text { in } \mathrm{mm}\end{array}$ & $\begin{array}{c}\text { Compressive } \\
\text { stress ( } 28 \\
\text { jrs) (Mpa) }\end{array}$ & $\begin{array}{l}\text { flexural } \\
\text { strength } \\
\text { (Mpa) }\end{array}$ & $\begin{array}{l}\text { splitting } \\
\text { tensile } \\
\text { strength } \\
\text { (Mpa) }\end{array}$ & $\begin{array}{c}\text { Density of } \\
\text { hardened } \\
\text { concrete } \\
\left(\mathrm{kg} / \mathrm{m}^{3}\right)\end{array}$ & $\begin{array}{c}\text { Porosity } \\
\text { (\%) }\end{array}$ \\
\hline \multirow[t]{2}{*}{$\begin{array}{l}\text { Flint from } \\
\text { phosphate mine } \\
\text { waste rocks [17] }\end{array}$} & $\begin{array}{l}\text { aggregates in } \\
\text { cement concrete }\end{array}$ & 0.5 & 0 & 70 & 34.4 & 4.5 & 2.5 & 2370 & \\
\hline & & & $100 \%$ & 50 & 29 & 4.9 & 2.6 & 2360 & \\
\hline \multirow[t]{3}{*}{$\begin{array}{l}\text { Phosphate mine } \\
\text { waste rocks [8] }\end{array}$} & $\begin{array}{l}\text { aggregates in } \\
\text { cement concrete }\end{array}$ & 0.5 & 0 & 70 & 29.6 & 2.5 & 4.5 & & \\
\hline & & 0.66 & 100 & 70 & 13.5 & 1.3 & 2.65 & & \\
\hline & Sand in mortar & 0.5 & 0 & & $\sim 32.5$ & & & & $\sim 38$ \\
\hline \multirow{4}{*}{$\begin{array}{l}\text { Gold-mine tailings } \\
\text { [13] }\end{array}$} & & & 10 & & $\sim 35$ & & & & $\sim 32$ \\
\hline & & & 20 & & $\sim 37.5$ & & & & $\sim 29.5$ \\
\hline & & & 30 & & $\sim 42$ & & & & $\sim 25.5$ \\
\hline & & & 40 & & $\sim 41.5$ & & & & - \\
\hline \multirow[t]{5}{*}{$\begin{array}{l}\text { Gold-mine tailings } \\
\text { [13] }\end{array}$} & $\begin{array}{l}\text { cement in } \\
\text { mortar }\end{array}$ & 0.5 & 0 & & $\sim 32.5$ & & & & $\sim 38$ \\
\hline & & & 10 & & $\sim 29.5$ & & & & $\sim 35.5$ \\
\hline & & & 20 & & $\sim 31.5$ & & & & $\sim 34$ \\
\hline & & & 30 & & $\sim 33$ & & & & $\sim 33.5$ \\
\hline & & & 40 & & $\sim 32$ & & & & - \\
\hline \multirow[t]{2}{*}{ Tailling plomb [15] } & $\begin{array}{l}\text { Sand in cement } \\
\text { concrete }\end{array}$ & & 0 & & 13.2 & & & & \\
\hline & & 1.35 & 100 & & $8.58-10.9$ & & & & $26.4-29.3$ \\
\hline \multirow[t]{7}{*}{ Copper tailing [5] } & $\begin{array}{l}\text { Sand in cement } \\
\text { concrete }\end{array}$ & $0.4-0.5$ & 0 & & $\sim 31-36$ & $\sim 4-4.5$ & & 2230.93 & \\
\hline & & & 10 & & $\sim 32-40$ & $\sim 4.6-4.8$ & & 2243.53 & \\
\hline & & & 20 & & $\sim 35-40$ & $\sim 4.2-4.7$ & & 2243.53 & \\
\hline & & & 30 & & $\sim 36-40$ & $\sim 4.1-4.5$ & & 2268.73 & \\
\hline & & & 40 & & $\sim 35-38$ & $\sim 4.2-4.5$ & & 2281.34 & \\
\hline & & & 50 & & $\sim 32-37$ & $\sim 4-4.5$ & & 2281.34 & \\
\hline & & & 60 & & $\sim 32-36$ & $\sim 4-4.4$ & & 2306.54 & \\
\hline \multirow[t]{3}{*}{$\begin{array}{l}\text { Waste rock gold } \\
\text { mine }[14]\end{array}$} & $\begin{array}{l}\text { aggregates in } \\
\text { concrete }\end{array}$ & 0.4 & $100 \%$ & 80 & 36 & & & & \\
\hline & $\mathrm{d} \geq 0.08 \mathrm{~mm}$ & & $100 \%$ & 80 & 33 & & & & \\
\hline & Gravels & & $100 \%$ & 75 & 40 & & & & \\
\hline \multirow[t]{2}{*}{$\begin{array}{l}\text { Waste rock gold } \\
\text { mining [9] }\end{array}$} & $\begin{array}{l}\text { aggregates in } \\
\text { cement concrete }\end{array}$ & 0.4 & 0 & 85 & 37.8 & & & & \\
\hline & & & $100 \%$ & 110 & 34.9 & & & & \\
\hline
\end{tabular}


Table 9. Leaching test for cementitious materials.

\begin{tabular}{|c|c|c|c|c|c|c|c|c|c|c|c|c|c|}
\hline \multirow{2}{*}{ Mining waste } & \multicolumn{3}{|c|}{$\begin{array}{l}\text { Concentration in leachate } \\
\qquad(\mathrm{mg} / \mathrm{L})\left(\text { with } \mathrm{H}_{2} \mathrm{O}\right)\end{array}$} & \multirow{2}{*}{$\begin{array}{c}\text { Sulphate } \\
\text { attack after } \\
28 \text { days } \\
\text { \% of weignt } \\
\text { loss }\end{array}$} & \multicolumn{9}{|c|}{$\begin{array}{l}\text { Cumulative concentrations of released metals during } \\
\text { the whole period of tank leaching test }\left(\mathrm{mg} / \mathrm{m}^{2}\right)\end{array}$} \\
\hline & $\mathrm{Cr}$ & $\mathrm{Pb}$ & $\mathrm{Cd}$ & & $\mathrm{SO} 4$ & As & $\mathrm{Ba}$ & $\mathrm{CO}$ & $\mathrm{Cu}$ & Mo & $\mathrm{Ni}$ & $\mathrm{Pb}$ & $\mathrm{Zn}$ \\
\hline \multirow[t]{3}{*}{$\begin{array}{l}\text { Gold-mine } \\
\text { tailings [13] }\end{array}$} & 0.141 & 0.0003 & $<0.00004$ & & & & & & & & & & \\
\hline & 0.124 & 0.0003 & $<0.00004$ & & & & & & & & & & \\
\hline & 0.108 & 0.0002 & $<0.00003$ & & & & & & & & & & \\
\hline \multirow{3}{*}{$\begin{array}{l}\text { Gold-mine } \\
\text { tailings [13] }\end{array}$} & 0.153 & 0.0004 & 0.00007 & & & & & & & & & & \\
\hline & 0.136 & 0.0002 & 0.00006 & & & & & & & & & & \\
\hline & 0.129 & 0.0003 & $<0.00005$ & & & & & & & & & & \\
\hline \multirow[t]{7}{*}{$\begin{array}{l}\text { Copper } \\
\text { tailing [5] }\end{array}$} & & & & $\sim 1.15-1.3$ & & & & & & & & & \\
\hline & & & & $\sim 1.25-1.26$ & & & & & & & & & \\
\hline & & & & $\sim 1.18-1.25$ & & & & & & & & & \\
\hline & & & & $\sim 1.18-1.35$ & & & & & & & & & \\
\hline & & & & $\sim 1.23-1.35$ & & & & & & & & & \\
\hline & & & & $\sim 1.25-1.4$ & & & & & & & & & \\
\hline & & & & $\sim 1.25-1.42$ & & & & & & & & & \\
\hline \multirow[t]{3}{*}{$\begin{array}{l}\text { Waste rock gold } \\
\text { mine }[14]\end{array}$} & & & & & $<100$ & $<100$ & $<1000$ & $<10$ & $<10$ & $<10$ & $<10$ & $<10$ & $<10$ \\
\hline & & & & & $<1000$ & $<100$ & $<100$ & $<10$ & $<10$ & $<10$ & $<10$ & $<10$ & $<10$ \\
\hline & & & & & $<1000$ & $<100$ & $<100$ & $<10$ & $<10$ & $<10$ & $<10$ & $<10$ & $<10$ \\
\hline \multirow[t]{2}{*}{$\begin{array}{l}\text { Waste rock gold } \\
\text { mining [9] }\end{array}$} & & & & & $<100$ & $<100$ & $<100$ & $<10$ & $<10$ & $<10$ & $<10$ & $<10$ & $<10$ \\
\hline & & & & & $<1000$ & $<100$ & $<100$ & $<10$ & $<10$ & $<10$ & $<10$ & $<10$ & $<10$ \\
\hline
\end{tabular}

\subsubsection{Mining Waste in Road Embankments}

Table 11 shows the characteristics of some mining wastes used in embankment materials such as coal mine waste rock and phosphate mine waste rock. It can be observed that mining wastes are used in road embankments according to their main properties, notably granulometry, sensitivity to water...

Mustapha Amrani et al. [18] observed that coal mine waste rock corresponds to very silty sands and gravels of medium hardness that can be used in the construction of pavements by respecting the compaction table proposed by the French guide for road works. Because of their CBR, they can be used as foundation materials.

Mustapha Amrani et al. [16] showed that Phosphate Mine Waste Rock can be 
Table 10. Characteristics of bricks from mining waste.

\begin{tabular}{|c|c|c|c|c|c|c|c|c|}
\hline Authors & Raw materials & $\begin{array}{l}\text { Drying/firing } \\
\text { conditions }\end{array}$ & $\begin{array}{l}\text { Apparent } \\
\text { density } \\
\left(\mathrm{g} / \mathrm{cm}^{3}\right)\end{array}$ & $\begin{array}{l}\text { Water } \\
\text { absorption } \\
(\%)\end{array}$ & $\begin{array}{l}\text { Apparent } \\
\text { porosity } \\
(\%)\end{array}$ & $\begin{array}{c}\text { Firing } \\
\text { shrinkage } \\
\quad(\%)\end{array}$ & $\begin{array}{l}\text { Flexural } \\
\text { strength } \\
(\mathrm{Mpa})\end{array}$ & $\begin{array}{l}\text { Compressive } \\
\text { strength } \\
\text { (Mpa) }\end{array}$ \\
\hline \multirow{4}{*}{$\begin{array}{l}\text { M. } \\
\text { Ettoumi et } \\
\text { al. [11] }\end{array}$} & $\begin{array}{l}100 \% \text { phosphate } \\
\text { sludge }\end{array}$ & Air drying for $24 \mathrm{~h}$ & $\sim 1.3$ & $12.5-17.2$ & $9-13$ & $5.2-7.5$ & $3.9-13.4$ & - \\
\hline & & Oven drying at $60^{\circ} \mathrm{C}$ for $24 \mathrm{~h}$ & & & & & & \\
\hline & & Firing at $900^{\circ} \mathrm{C}, 1000^{\circ} \mathrm{C}$ and & & & & & & \\
\hline & & $\begin{array}{l}1100^{\circ} \mathrm{C} \text { for } 3 \mathrm{~h} \text { (heating rate } \\
\text { of } 120^{\circ} \mathrm{C} / \mathrm{h} \text { ) }\end{array}$ & & & & & & \\
\hline \multirow[t]{4}{*}{$\begin{array}{l}\text { Luo et al. } \\
{[31]}\end{array}$} & $\begin{array}{l}48 \%-60 \% \text { iron ore } \\
\text { tailings }\end{array}$ & Air drying for $48 \mathrm{~h}$ & & & & & & \\
\hline & $10 \%$ shale & Oven drying at $105^{\circ} \mathrm{C}$ for $24 \mathrm{~h}$ & & & & & & \\
\hline & $\begin{array}{l}30 \% \text { coal gangue } \\
\text { powder }\end{array}$ & $\begin{array}{l}\text { Firing at } 950^{\circ} \mathrm{C}, 1000^{\circ} \mathrm{C} \text {, and } \\
1100^{\circ} \mathrm{C} \text { for } 2 \mathrm{~h}, 2,5 \mathrm{~h}, 3 \mathrm{~h}, 3.5 \\
\mathrm{~h} \text { and } 4 \mathrm{~h} \text { (heating rate of } \\
300^{\circ} \mathrm{C} / \mathrm{h} \text { ) }\end{array}$ & $\sim 1.62-1.74$ & $14-18$ & - & - & - & $8.5-17.5$ \\
\hline & $\begin{array}{l}0-12 \% \text { sewage } \\
\text { sludge }\end{array}$ & & & & & & & \\
\hline \multirow[t]{3}{*}{$\begin{array}{l}\text { Loutou et } \\
\text { al. [32] }\end{array}$} & $\begin{array}{l}100 \% \text { clay } \\
\text { by-product (red } \\
\text { clay) from } \\
\text { phosphate mines }\end{array}$ & Air drying for $24 \mathrm{~h}$ & $\sim 1.7-2.6$ & $3-17$ & $7-22$ & $\sim 1.5-3.4$ & $17-36$ & \\
\hline & & Oven drying at $105^{\circ} \mathrm{C}$ for $24 \mathrm{~h}$ & & & & & & \\
\hline & & $\begin{array}{l}\text { Firing at } 900^{\circ} \mathrm{C}, 1000^{\circ} \mathrm{C} \text { and } \\
1100^{\circ} \mathrm{C} \text { for } 2 \mathrm{~h}\end{array}$ & & & & & & \\
\hline \multirow[t]{3}{*}{$\begin{array}{l}\text { Taha et al. } \\
\text { [33] }\end{array}$} & $\begin{array}{l}10 \%-50 \% \text { treated } \\
\text { calamine processing } \\
\text { mine tailing }\end{array}$ & Air drying for $24 \mathrm{~h}$ & $\sim 1.6-1.9$ & $12-26$ & $22-42$ & $1-8$ & $3.5-11.8$ & \\
\hline & $\begin{array}{l}5 \%-15 \% \text { glass } \\
\text { waste }\end{array}$ & Oven drying at $60^{\circ} \mathrm{C}$ for $24 \mathrm{~h}$ & & & & & & \\
\hline & $\begin{array}{l}45 \%-85 \% \text { shale } \\
\text { for brick }\end{array}$ & $\begin{array}{l}\text { Firing at } 900^{\circ} \mathrm{C}, 1000^{\circ} \mathrm{C} \text { and } \\
1100^{\circ} \mathrm{C} \text { for } 5 \mathrm{~h} \text { (heating rate } \\
\text { of } 48^{\circ} \mathrm{C} / \mathrm{h} \text { ) }\end{array}$ & & & & & & \\
\hline \multirow[t]{3}{*}{$\begin{array}{l}\text { Yang et al. } \\
\text { [34] }\end{array}$} & $\begin{array}{l}80 \%-100 \% \text { iron } \\
\text { tailings }\end{array}$ & Air drying for $12 \mathrm{~h}$ & $\sim 1.8-2.0$ & $15.5-17.5$ & $27-34$ & $0.9-1.2$ & & $6-27$ \\
\hline & $0-20 \%$ fly ash & $\begin{array}{l}\text { Oven drying at } 35^{\circ} \mathrm{C} \text { for } 12 \mathrm{~h} \\
\text { then at } 105^{\circ} \mathrm{C} \text { for } 8 \mathrm{~h}\end{array}$ & & & & & & \\
\hline & & $\begin{array}{l}\text { Firing at } 900^{\circ} \mathrm{C}, 950^{\circ} \mathrm{C} \text { and } \\
1000^{\circ} \mathrm{C} \text { for } 2 \mathrm{~h} \text { (heating rate } \\
\text { of } 120 \mathrm{C} / \mathrm{h} \text { ) }\end{array}$ & & & & & & \\
\hline
\end{tabular}

used as an alternative material in the construction of dry compacted embankments. The results show that these water insensitive materials can be dry compacted, with dry densities above $95 \%$ of the Proctor. Due to their CBR, they can 
Table 11. Characteristics of backfill from mine waste.

\begin{tabular}{|c|c|c|c|c|c|c|c|}
\hline \multirow[b]{2}{*}{ Waste } & \multicolumn{2}{|c|}{ Proctor Normal } & \multicolumn{2}{|c|}{ Modified Proctor } & \multicolumn{2}{|l|}{ CBR } & \multirow[b]{2}{*}{$\begin{array}{l}\text { Use in road } \\
\text { construction }\end{array}$} \\
\hline & $\begin{array}{l}\text { Wopt } \\
(\%)\end{array}$ & $\begin{array}{c}\text { Pd opt } \\
\left(\mathrm{kN} / \mathrm{m}^{3}\right)\end{array}$ & $\begin{array}{l}\text { Wopt } \\
(\%)\end{array}$ & $\begin{array}{c}\text { Pd opt } \\
\left(\mathrm{kN} / \mathrm{m}^{3}\right)\end{array}$ & $\begin{array}{l}\text { CBR } \\
4 \mathrm{i} \%\end{array}$ & $\begin{array}{l}\text { IBI } \\
\%\end{array}$ & \\
\hline $\begin{array}{l}\text { Coal mine waste rock } \\
\text { [18] }\end{array}$ & 11.2 & 19 & 10.11 & 20.4 & 9 & 29 & Sub-base layer \\
\hline $\begin{array}{l}\text { Phosphate mine waste } \\
\text { rock [16] }\end{array}$ & $12.9-14.60$ & 17.9 & - & - & 13 & - & $\begin{array}{c}\text { Sub-base layer and } \\
\text { backfill }\end{array}$ \\
\hline
\end{tabular}

be used as foundation materials.

In general, mining wastes with characteristics of road materials such as grading, impact and wear resistance are a good choice for road embankments. Furthermore, the results of different studies have shown that these materials (mine waste) should be tested for leaching to prevent soil contamination. However, the mixing of mine waste with other constituents such as stabilisers is a factor influencing the behaviour of mine waste fills.

\section{Conclusion}

This paper is based on an extensive review of about thirty authors who have dealt with the valorisation of mining waste in construction materials. In addition to the presentation of the origins of mining waste, the different properties have been sculpted firstly the physical, mechanical, chemical, mineralogical, heavy metal content, geotechnical and environmental properties have been examined and secondly the properties of the materials containing the mining waste have been sculpted. The use of tailings and waste rocks in cementitious materials offers convincing results; the valorisation of slags is practical in fired bricks. The few research studies obtained on the use of mining waste in road embankments have shown that mining waste can be used as a sub-base layer and backfill as long as it is not toxic. Several other mining wastes produced in mining operations, which are subject to pollution and clutter, require special attention with regard to their likely use in construction materials. By way of illustration, attention can be drawn to coltan mining waste, cobalt and cassiterite waste, where there is not enough literature.

\section{Conflicts of Interest}

The authors declare no conflicts of interest regarding the publication of this paper.

\section{References}

[1] Yassine, T. (2017) Valorisation des rejets miniers dans la fabrication de briques cuites: Evaluations technique et environnementale, Université du Québec en Abitibi Témiscamingue, Quebec.

[2] Lottermoser, B.G. (2010) Mine Wastes: Characterization, Treatment and Environ- 
mental Impacts. Springer, Berlin. https://doi.org/10.1007/978-3-642-12419-8

[3] Ahmari, S. and Zhang, L. (2012) Production of Eco-Friendly Bricks from Copper Mine Tailings through Geopolymerization. Construction and Building Materials, 29, 323-331. https://doi.org/10.1016/j.conbuildmat.2011.10.048

[4] Lia, C., Sunab, H., Baic, J. and Li, L. (2010) Innovative Methodology for Comprehensive Utilization of Iron Ore Tailings: Part 2: The Residues after Iron Recovery. Journal of hazardous materials, 174, 78-83. https://doi.org/10.1016/j.jhazmat.2009.09.019

[5] Thomas, B.S., Damare, A. and Gupta, R. (2013) Strength and Durability Characteristics of Copper Tailing Concrete. Construction and Building Materials, 48, 894-900. https://doi.org/10.1016/j.conbuildmat.2013.07.075

[6] Lv, X., Shen, W., Wang, L., Dong, Y., Zhang, J. and Xie, Z. (2018) A Comparative Study on the Practical Utilization of Iron Tailings as a Complete Replacement of Normal Aggregates in Dam Concrete with Different Gradation. Journal of Cleaner Production, 211, 704-715. https://doi.org/10.1016/j.jclepro.2018.11.107

[7] Lèbre, É., Corder, G.D. and Golev, A. (2017) Sustainable Practices in the Management of Mining Waste: A Focus on the Mineral Resource. Minerals Engineering, 107, 34-42. https://doi.org/10.1016/j.mineng.2016.12.004

[8] El Machi, A., Mabroum, S., Taha, Y., Tagnit-Hamou, A., Benzaazoua, M. and Hakkou, R. (2021) Valorization of Phosphate Mine Waste Rocks as Aggregates for Concrete. Materials Today: Proceedings, 37, 3840-3846.

https://doi.org/10.1016/j.matpr.2020.08.404

[9] Benarchid, Y., Taha, Y., Argane, R. and Benzaazoua, M. (2018) Application of Quebec Recycling Guidelines to Assess the Use Feasibility of Waste Rocks as Construction Aggregates. Resources Policy, 159, 68-76.

https://doi.org/10.1016/j.resourpol.2018.01.004

[10] Amrani, M., Taha, Y., Elghali, A., Benzaazoua, M., Kchikach, A. and Hakkou, R. (2021) An Experimental Investigation on Collapsible Behavior of Dry Compacted Phosphate Mine Waste Rock in Road Embankment. Transportation Geotechnics, 26, Article ID: 100439. https://doi.org/10.1016/j.trgeo.2020.100439

[11] Ettoumi, M., Jouini, M., Neculita, C., Bouhlel, S., Coudert, L., Taha, Y. and Benzaazoua, M. (2021) Characterization of Phosphate Processing Sludge from Tunisian Mining Basin and Its Potential Valorization in Fired Bricks Making. Journal of Cleaner Production, 284, Article ID: 124750. https://doi.org/10.1016/j.jclepro.2020.124750

[12] Pyo, S., Tafesse, M., Kim, B.-J. and Kim, H.-K. (2018) Effects of quartz-Based Mine Tailings on Characteristics and Leaching Behavior of Ultra-High Performance Concrete. Construction and Building Materials, 166, 110-117. https://doi.org/10.1016/j.conbuildmat.2018.01.087

[13] Ince, C. (2019) Reusing Gold-Mine Tailings in Cement Mortars: Mechanical Properties and Socio-Economic Developments for the Lefke-Xeros Area of Cyprus. Journal of Cleaner Production, 238, Article ID: 117871. https://doi.org/10.1016/j.jclepro.2019.117871

[14] Taha, Y., Benarchid, Y. and Benzaazoua, M. (2019) Environmental Behavior of Waste Rocks Based Concrete: Leaching Performance Assessment. Resources Policy, Article ID: 101419. https://doi.org/10.1016/j.resourpol.2019.101419

[15] Argane, R., Benzaazoua, M., Hakkou, R. and Bouamrane, A. (2015) Reuse of Base-Metal Tailings as Aggregates for Rendering Mortars: Assessment of Immobilization Performances and Environmental Behavior. Construction and Building Materials, 96, 
296-306. https://doi.org/10.1016/j.conbuildmat.2015.08.029

[16] Amrani, M., Taha, Y., Kchikach, A., Benzaazoua, M. and Hakkou, R. (2019) Valorization of Phosphate Mine Waste Rocks as Materials for Road Construction. Minerals, 9, Article No. 237. https://doi.org/10.3390/min9040237

[17] Machi, A.E., Mabroum, S., Taha, Y., Tagnit-Hamou, A., Benzaazoua, M. and Hakkou, R. (2021) Use of Flint from Phosphate Mine Waste Rocks as an Alternative Aggregates for Concrete. Construction and Building Materials, 271, Article ID: 121886. https://doi.org/10.1016/j.conbuildmat.2020.121886

[18] Amrani, M., Taha, Y., Haloui, Y.E., Benzaazoua, M. and Hakkou, R. (2020) Sustainable Reuse of Coal Mine Waste: Experimental and Economic Assessments for Embankments and Pavement Layer Applications in Morocco. Minerals, 110, Article No. 851. https://doi.org/10.3390/min10100851

[19] US-EPA (U.S. Environmental Protection Agency) (2009) A User-Friendly Reference Document for Hazardous Waste Characteristics. United States Environmental Protection Agency, Washington DC.

[20] Glavind, M. (2009) Sustainability of Cement, Concrete and Cement Replacement Materials in Construction. In: Khatib, J.M., Ed., Sustainability of Construction Materials, Woodhead Publishing, 120-147. https://doi.org/10.1533/9781845695842.120

[21] Monteiro, P. (2006) Microstructure, Properties, and Materials. No. 13, McGraw-Hill, New York.

[22] Beushaus, H. and Dittmer, T. (2015) The Influence of Aggregate Type on the Strength and Elastic Modulus of High Strength Concrete. Construction and Building Materials, 74, 132-139. https://doi.org/10.1016/j.conbuildmat.2014.08.055

[23] Chi, J., Huang, R., Yang, C. and Chang, J. (2003) Effect of Aggregate Properties on the Strength and Stiffness of Lightweight Concrete. Cement and Conrete Composites, 25, 197-205. https://doi.org/10.1016/S0958-9465(02)00020-3

[24] Yellishetty, M., Karpe, V., Reddy, E., Subhash, K. and Ranjith, P. (2008) Reuse of Iron Ore Mineral Wastes in Civil Engineering Constructions: A Case Study. Ressources, Conservation and Recycling, 52, 1283-1289.

https://doi.org/10.1016/j.resconrec.2008.07.007

[25] Ramachandran, V.S. (1981) Waste and By-Products as Concrete Aggregates. Vol. 215, National Research Council of Canada.

[26] Blengini, G.A., Garbarino, E., Šolar, S., Shields, D.J., Hámor, T., Vinai, R. and Agioutantis, Z. (2012) Life Cycle Assessment Guidelines for the Sustainable Production and Recycling of Aggregates: The Sustainable Aggregates Resource Management Project (SARMa). Journal of Cleaner Production, 27, 177-181.

https://doi.org/10.1016/j.jclepro.2012.01.020

[27] Coppola, L., Buoso, A., Coffetti, D., Kara, P. and Lorenzi, S. (2016) Electric Arc Furnace Granulated Slag for Sustainable Concrete. Construction and Building Materials, 123, 115-119. https://doi.org/10.1016/j.conbuildmat.2016.06.142

[28] Hakkou, R., Benzaazoua, M. and Bussière, B. (2016) Valorization of Phosphate Waste Rocks and Sludge from the Moroccan Phosphate Mines: Challenges and Perspectives. Procedia Engineering, 138, 110-118.

https://doi.org/10.1016/j.proeng.2016.02.068

[29] Bayoussef, A., Loutou, M., Taha, Y., Mansori, M., Benzaazoua, M., Hakkou, B.M. and Hakkou, R. (2020) Use of Clays By-Products from Phosphate Mines for the Manufacture of Sustainable Lightweight Aggregates. Journal of Cleaner Production, 280, Article ID: 124361. https://doi.org/10.1016/j.jclepro.2020.124361 
[30] Grâce, M.M., Ally, A.N., Abdias, M., Binwa, K., Muhatikani, K., Marcelline, M. and François, N. (2020) Concrete Based on Recycled Aggregates for Their Use in Construction: Case of Goma (DRC). Open Journal of Civil Engineering, 10, 226-238. https://doi.org/10.4236/ojce.2020.103019

[31] Luo, L., Li, K., Fu, W., Liu, C. and Yang, S. (2020) Preparation, Characteristics and Mechanisms of the Composite Sintered Bricks Produced from Shale, Sewage Sludge, Coal Gangue Powder and Iron Ore Tailings. Construct. Construction and Building Materials, 232, Article ID: 117250.

https://doi.org/10.1016/j.conbuildmat.2019.117250

[32] Loutou, M., Misrar, W., Koudad, M., Mansori, M., Grase, L., Favotto, C., Taha, Y. and Hakkou, R. (2019) Phosphate Mine Tailing Recycling in Membrane Filter Manufacturing: Microstructure and Filtration Suitability. Minerals, 9, Article No. 318. https://doi.org/10.3390/min9050318

[33] Yassine, T., Mostafa, B., Mohammed, M. and Rachid, H. (2017) Recycling Feasibility of Glass Wastes and Calamine Processing Tailings in Fired Bricks Making. Waste and Biomass Valorization, 8, 1479-1489. https://doi.org/10.1007/s12649-016-9657-3

[34] Yang, C., Cui, C., Qin, J. and Cui, X. (2014) Characteristics of the Fired Bricks with Low-Silicon Iron Tailings. Construction and Building Materials, 70, 36-42.

https://doi.org/10.1016/j.conbuildmat.2014.07.075 